\title{
SOME STANDARD CLAUSES IN PETROLEUM INDUSTRY AGREEMENTS - AN INQUIRY
}

\section{A. J. KOVACH*}

This paper examines a number of clauses commonly included in farmout, unitization and other oil and gas agreements. Drawing upon the Canadian Association of Petroleum Landmen 1974 Operating Procedure, it scrutinizes force majeure, arbitration, notice. and other clauses, with a view to determining their effectiveness.

In their discussion on pooling and unitization agreements, the authors of Williams \& Meyers' remarked that in addition to clauses subject to negotiation and hard bargaining "... others ... are customarily included as a safe-guard against subsequent dispute but concerning which serious bargaining or disagreement may not be expected. The fact that there may be no dispute over such provisions should not cause them to be overlooked."

In one form or another, the kind of clauses that the authors Williams \& Meyers had in mind have probably been included in the majority of petroleum industry contracts. In many cases, however, those clauses have been included without the draftsmen fully appreciating their ramifications and limitations. There is surprisingly little published material on the construction of boiler plate clauses. This comparative silence may be a tribute to the skill of the draftsman or to the conciliatory nature of the contracting parties. Or it may reflect a naked lack of interest in the subject.

The following discussion is intended to illustrate that there may be some benefit in a re-examination of provisions routinely used. The clauses for scrutiny have been selected arbitrarily:
1. Force Majeure;
2. Arbitration;
3. Notices;
4. Operator's Lien; and
5. Operator's Liability.

While provisions bearing titles more or less the same are common, their content is not. Illustrations have been derived from the Canadian Association of Petroleum Landmen 1974 Operating Procedure (hereinafter called the "CAPL" form) in order to avoid any accusation of partiality. This paper is not to be construed as criticism or a critique of the CAPL document.

*Solicitor, Shell Canada Resources Limited, Calgary, Alberta.

1. 6 Williams \& Meyers, Oil \& Gas Law 503 (1959).

2. Matsoukis v. Priestman \& Co. [1915] 1 K.B. 681, Bailhache, J. at 685: "The words 'force majeure' are not words which we generally find in an English contract. They are taken from the Code Napoleon... I have had the evidence of a Belgian lawyer as to their meaning, and he said that the words are understood on the Continent to mean 'causes you cannot prevent and for which you are not responsible' ... I cannot accept the argument that the words are interchangeable with 'vis major' or 'Act of God' ... I am quite satisfied that I ought to give them a more extensive meaning than 'Act of God' or 'vis major'. "While his Lordship found it difficult "to say how much more extensive", he held ". . . that the complete dislocation of business in the north of England as a consequence of a universal coal strike ... did come within the reasonable meaning of the words 'force majeure". He held at 687 that the. term "... cannot, however, in any (sic) view, be extended to cover bad weather, football matches, or a funeral." 


\section{FORCE MAJEURE}

"Force Majeure" is a term derived from the Code Napoleon and has not had a completely comfortable introduction into the common law. 2 Along with "vis major", it has been taken to correspond with "Act of God". It is construed as meaning "irresistible or superior force", and an "insuperable interference occurring without the party's intervention" which "could not have been prevented by prudence, diligence, or care". ${ }^{3}$

Under the common law doctrines of "frustration", "commercial frustration" and "impossibility of performance", a party was relieved from his absolute obligation to perform his contract only if, subsequent to making the contract, extraordinary circumstances occurred that neither were foreseeable nor within his reasonable control, and that thereby prevented him from performing because performance was impossible or illegal. As Mr. Coté has observed, these theories or doctrines are creatures "of the law or the court, not the parties".4 Worse still, their applicability in individual cases was very uncertain. ${ }^{5}$ In this atmosphere it is not surprising that contracting parties established their own rules through the creation of Force Majeure clauses. Some of these have achieved a remarkable degree of exculpatory sophistication. They are used as a matter of course to avoid any possibility that a court would refuse to imply such terms and grant relief when the contract cannot be performed or is frustrated in a commercial sense. As long ago as 1951, Professor Merrill remarked in connection with Force Majeure clauses in oil and gas leases that "... it seems that hardly anything which might interfere with the lessee's activities have been left out," including in some drafts, causes that render performance "unreasonably burdensome". ${ }^{6} \mathrm{He}$ added that "some drafts not only excuse compliance during the time of governmental hindrance, but also for periods as long as one year after the interfering law or order comes to an end."7

Clause 16.01 of the CAPL form defines "Force Majeure" as meaning:

... any one or more of the following events:

(a) an Act of God,

(b) a war, revolution, insurrection, riot, blockade or any other unlawful act against public order or authority.

(c) a strike, walkout, or other industrial disturbance,

(d) a storm, fire, flood, explosion or lightning,

(e) a governmental restraint.

(f) any other event (whether or not of the kind enumerated in (a) to (e) of this Clause) which is not reasonably within the control of the party hereto claiming suspension of its obligations hereunder due to Force Majeure.

3. Brown, The Law of Oil and Gas Leases, s. 13.01 (1967).

4. Cote, An Introduction to the Law of Contract, 224 (1974).

5. See Ziger v. Shiffer \& Hillman Co. [1993] 2 D.L.R. 691 (C.A.), a case where the court implied a term in a contract that did not contain an exculpatory provision and granted relief from liability where performance was rendered impossible by labour violence. The case involved "mob violence" and "hired thugs imported from the United States", and therefore probably it was difficult for the court to imply the relieving term than would have been the case in a less dramatic situation.

6. Merrill, Lease Clauses Affecting Implied Covenants, Second Annual Institute on Oil \& Gas Law, 141 at $190-1$.

7. Id. 
Typically, the draftsman sought to avoid any application of ejusdem generis to paragraph (f) that might have arisen out of the specific enumeration in the earlier paragraphs. Clause 16.04 refines the definition further to establish "that lack of finances" are "not to be considered a Force Majeure". The substantive provision appears in Clause 16.02, providing for a suspension of a party's obligations to perform the contract so long as the intervening Force Majeure event continues, subject to the obligation, as set out in Clause 16.03, to "promptly remedy ... in so far as it is reasonably able to do so".

The common law authorities interpreting claims for Force Majeure relief indicate no doubt ". . . that the burden lies upon the [claiming party] ... to establish that the interruption or suspension ... was the result of a cause or causes beyond the respondent's control, other than lack of funds". 8 The American authorities view the burden similarly:9

It is clear that the burden of proof is on the party seeking to establish the existence of facts that make a Force Majeure provision operative.

It is a sobering exercise to examine the judgments of the majority of the Alberta Court of Appeal in Canada-Cities Service Petroleum v. Kininmonth 10 as an indication of how formidable this burden may be. Conceivably, the burden may have been particularly difficult in that case as the court was construing the obligations of a lessee attempting to maintain its lease upon the expiration of the ten-year primary term. But there is no rationale in the judgments indicating that different criteria would be applied to Force Majeure claims under other legal relationships. As Mr. Williams observed, "There is surprisingly little case law on Force Majeure provisions in mineral contracts. Much of the case law that does exist relates to oil and gas leases." "The Kininmonth case is nevertheless instructive regarding judicial attitudes toward claims based on Force Majeure provisions, regardless of the nature of the legal relationship.

In the Kininmonth case the respondent argued that a municipal road ban was a cause beyond its control, rendering it unable to complete the fracturing necessary to obtain production before expiration of the primary term of the lease. It was argued that the Force Majeure provisions of the lease entitled the lessee to a declaration that the lease continued in force. Chief Justice Smith held that in order to rely upon a municipal road ban as a cause beyond the lessee's control, the road ban had to be valid; he held that it was invalid. He added that in all probability the lessee could have obtained a road permit if it had applied for one, and that the evidence did not show that it had; the spring closing of the country roads to heavy traffic was so notorious in the province that the lessee should have anticipated the road closing and taken appropriate advance action. Mr. Justice Porter stated that the order of the Conservation Board that stopped production was also foreseeable by the lessee and that the lessee should have applied for permission to produce from a spacing unit smaller than usual. The

\footnotetext{
8. Canada-Cities Service Petroleum Corporation v. Kininmonth (1963) 44 W.W.R. 392 , Smith C.J.A. at 394.

9. Williams, Coping with Acts of God, Strikes \& Other Delights, Twenty-Second Annual Rocky Mountain Mineral Law Institute 438 at 439.

10. Supra, n. 8.

11. Williams, supra, n. 9 at 434.
} 
court imputed that the lessee foresaw or should have foreseen the looming difficulties and it was obliged not only to take every possible reasonable action to avoid or overcome these possibilities, but also had to demonstrate that it had done so.

The decisions illustrate that regardless of the particular wording of the lease in question, (or, it is suggested, in a commercial agreement) there are several ingredients to a successful claim based on the "normal" Force Majeure provision. The party claiming relief must establish that the event in question is the proximate cause, that it was not foreseeable, that the claimant tried to overcome the event which was beyond its control, and that the burden of doing so is entirely on that claiming party.

From the aspect of proximate cause, the lessee in Kininmonth failed to establish that the problem confronting it could not have been solved by applying for permission to produce from the smaller spacing unit, for permission to transport its fracturing equipment overland, or for an overweight permit allowing the use of the road by the overweight vehicles. As a result, no proximate cause was established.

As to foreseeability, Chief Justice Smith said ". . . it is so well known in Alberta that roads of this type are ordinarily closed for heavy traffic ... during the spring that the courts are entitled to take judicial notice of this practice. The closing of the roads could and should have been anticipated." 12 Porter, J. A. added that ". . the coming of a road ban in this country is as certain as the coming of spring. It is not only foreseeable but it was forseen by the respondent ..."1s

As to efforts to overcome the event, Porter,J. A. said further at 411:

The only excuse for the respondent's failure to have [fracturing equipment] on hand was one of cost which impressed an employee ... as being what he thought excessive .... It is the practice to permit heavy vehicles to use the road notwithstanding the ban if the user satisfies - that it will pay for the damage...

His Lordship obviously considered economic considerations, at least in these circumstances, insufficient to relieve the party from its obligations.

Clause 16.03 of CAPL requires the claiming party to "... promptly remedy ... insofar as it is reasonably able to do so;". Those words indicate the possibility that a court might say that the effort required is individual to the claiming party, and that greater effort may be required of one party than another. Most Force Majeure clauses may be susceptible to the same kind of interpretation. However, the better opinion is probably that the courts will impose an objective standard in assessing the claim unless the wording unambiguously establishes a contrary intent.14

The exculpatory words in the lease considered in Kininmonth contained no remedial requirements comparable to the terms in the CAPL form, but the Court of Appeal had no problem in finding that the claimant was obliged to exercise remedial efforts. The court appeared

12. Supra, n. 8 at 396.

13. Id. at 411 .

14. See the discussion by Veitch, Contracts - Frustration - Force Majeure Clauses, (1976) 54 Can. Bar Rev. 161 at 168-9, concerning the decisions in Atlantic Paper Stock Ltd. v. St. Anne-Nackawic Pulp and Paper Co. Ltd. (1974) 46 D.L.R. (3d) 732 (N.B.S.C.) and (1975) 56 D.L.R. (3d) 409 (S.C.C.). 
to approach the requirement for remedial efforts on the basis of an objective standard. Since "lack of finances" is a cause almost invariably excluded from Force Majeure relief, it is unlikely that any court would find economic considerations a legitimate excuse for inadequate efforts to overcome the Force Majeure event.

If the supervening event is a governmental action, rule, or order, there may be a burden on the claiming party to attempt to overcome the inhibiting cause. Earl A. Brown's describes an American decision which he says is such a case. He says that Haby v. Stanolind Oil and Gas Company 16 indicates that at least in cases of governmental orders that interfere with the lessee's performance under a lease, "[I]f there is more than one way to carry out performance in perpetuating a lease, an order which prevents one method of performance will not excuse if the lease requirement can be satisfied in another manner."17 The court in Haby held that the evidence did not warrant a finding of more than an economical impracticability to produce under the circumstances of the order, as distinguished from an impossibility to produce. It was pointed out that the lessee could have kept the lease in force by commencing the drilling of another well within the sixty day period designated in the lease, even though the lessee was constructing a plant for the processing and marketing of gas from a shut-in well from which gas production had previously been flared. Kininmonth may not have been as extreme on the facts, but the reasoning was of the same cloth.

Rarely do Force Majeure clauses omit a description of a number of calamitous events that would give rise to a claim for relief. The prospect of an ejusdem generis construction in such a case is well known, and is therefore mentioned here only as a reminder. The parties may be well advised to include in the list of Force Majeure causes potential causes that are reasonably foreseeable as a hindrance to performance in the particular venture and which might not be construed as Force Majeure causes if they were not listed. Because of the foreseeability principle, this may be very good practice. Probably with this in mind, one commentator recommended that "standard" Force Majeure clauses be avoided "... in order that the Force Majeure provision may address the types of problems that are most likely to occur and with respect to which the parties desire to provide Force Majeure relief." 18 Another writer has suggested that in purchase and sale contracts, "from the supplier's point of view the acme of perfection lies in an exhaustive and detailed clause which expressly covers all possible, not to say foreseeable, eventualities"19 (emphasis added). A more elaborate Force Majeure provision specifically addressed to road bans, etc., might have provided the lessee in Kinimonth stronger grounds for relief.

Since parties can create their own rules of Force Majeure, they may wish to provide a more precise standard of conduct for overcoming the Force Majeure event than "reasonable" or "due diligence". It

15. Brown, supra, n. 3, s. 19.04.

16. 228 F. (2d) 28 (5th Circ. 1955).

17. Brown, supra, n. 3 at 13.04.

18. Williams, supra, n. 9 at 448.

19. Veitch, supra, n. 14 at 164. 
would appear to be unwise for a party to rely on the "commercial impracticability" feature that is available to relieve a party in respect of sale of goods contracts under the U.S. Uniform Commercial Code.20

The expansion of Force Majeure relief may be an appropriate subject for discussion or speculation, but the scope is necessarily subject to practical limitations, especially in the oil industry where frequently only one party conducts the activities affected by Force Majeure causes. Rarely would a non-Operator be prepared to excuse performance by causes that could not realistically be described as beyond the Operator's reasonable control.

\section{ARBITRATION}

Arbitration clauses have a vogue in industry agreements that may be excessive in relation to their practical value. This is not to suggest that arbitration is not a useful and perhaps essential mechanism for resolving differences (as, for example, if the issue is one of fact or the redetermination of price under a long term contract). In those cases it is probably far more appropriate than a judicial determination. The purpose of this discussion is to point out that the arbitration procedure may not provide the simple, economical and prompt resolution of differences that the parties expect. It appears that arbitration is a procedure used frequently and effectively in the construction industry. Perhaps the effectiveness of the procedure is a function of the frequency with which it is used. It is likely to be most effective where a well-established body of professional arbitrators has been produced, and where the industry itself has developed the required mechanics and expertise.

One of the elements essential to satisfactory arbitration proceedings is that the parties urgently wish the procedure to succeed and cooperate in its completion. In the petroleum industry, that may not always be the case. One party may find a particular advantage in refusing to cooperate, thereby achieving advantageous delays. The scope for advantage is in direct proportion to the number of procedural steps available or required in the proceedings.

The complexeties of the arbitration procedure may be illustrated by a price redetermination case which occurred several years ago. The contract in question provided that if either party wished to redetermine price, it was obliged to give the other written notice of its intention. If, following the giving of notice, the parties were unable to agree on the price, the matter was to be submitted to a single arbitrator. If the parties were unable to agree upon a single arbitrator, a panel of three was to be struck, one chosen by each party and the third by the two selected arbitrators. It will simplify the narrative if one assumes that, notwithstanding the provision in the agreement that the redetermined price was to become effective only at a prescribed time following the arbitrator's award, both parties cooperated in all respects other than in the selection of the sole arbitrator. Each party had the task of locating an arbitrator who, by education, training and experience, it considered to be qualified to assess the matter, namely, a busy person. The two arbitrators selected were then required to locate a mutually-acceptable third person with like qualification -

20. U.C.C. s. 2. 
and therefore subject to similar demands. (In fact, the selection of the third man was made by the principals, but the concerns remained the same.) Thereupon the entire panel had to select a suitable period of time to allocate to the proceeding, considering not only their availability, but also the availability of at least one well-qualified expert for each of the parties. Each expert required time to conduct studies or, to consult authorities, and accordingly had limited availability for the proceedings. Then the additional problem of the availability of each party's counsel for the same time slot arose. The petroleum industry's roster of preferred counsel is limited, as is their availability. Anyone contemplating arbitration should therefore take heed of the schedules of any extensive National Energy Board hearings or exercises such as the Berger Inquiry. Even in the best possible circumstances one can be assured of participating in a very demanding exercise in logistics.21

All of foregoing considerations exist even when each party is pressing for a resolution. However, where a party might benefit from a delay, an excess of imagination is not required to inhibit the orderly progress of proceedings. The party can decline to appoint its arbitrator or decline to agree to the selection of the third arbitrator. In each case, court applications will probably be required. Generally, provision for court appointments should be included in the arbitration clause. In Alberta, it is probably recommended procedure since there seems some doubt as to the effectiveness of 5.5 of The Alberta Arbitration Act22 where one party has appointed its arbitrator but the other refuses to do so.23 These court proceedings necessarily take time and may throw the well-synchronized schedules out of phase for at least some of the participants. The dismay of the party responsible for the organization and coordination of what his principal assumed was an economical, expeditious and efficient method for resolving differences is probably understandable.

The only apparent solution to these potential problems is to provide in the agreement that the arbitration procedure be as simple as possible. There could be significant savings in time and avoidance of logistics problems by providing for only a single arbitrator, to be appointed by the court if the parties fail to agree on the selection. If the three man arbitration panel splits, it is arguable that the decision is made ultimately by the one member who creates the majority. It is suggested, therefore, that objections to a single arbitrator (as opposed to a three person panel) may have more an emotional than realistic foundation, on the probably false assumption that the party's selected arbitrator will function more as an advocate than an arbitrator.24 If a party is concerned about the possibility of the other party's delaying tactics, this method merits serious consideration.

In the proper case, arbitration proceedings seem to provide an

21. For a good chronical of a specific proceeding and some procedural guidelines, see Holland, Thoughts on the Arbitration of Price Redetermination Under Gas Purchase Contracts in Alberta, (1974) 12 Alta. L. Rev. 28 at $29 \cdot 31$.

22. R.S.A. 1970, c. 21.

23. See appendix B to Burrows, A Study of the Role of Arbitrators in Commercial Arbitration Proceeding8, (1976) 14 Alta. L. Rev. 302 at 318.

24. Mr. Holland, supra, $\mathbf{n . 2 1}$ at 30 suggests that this may be the case. If so, do the parties really want their case argued twice - first by counsel and then by the arbitrators? 
efficient machinery for resolving differences quickly. However, the procedure should not be considered a panacea. The ramifications of arbitration and arbitration procedures should be considered carefully before adoption of the formula.

\section{NOTICES}

\section{The CAPL "Notices" clause (2201) reads in part as follows:}

... all notices, communications and statements . . . required or permitted . . shall be in writing. Notices may be served:

(a) Personally by leaving them with the party on whom they are to be served at the party's address ... Personally served notices shall be deemed received ... when actually delivered provided such delivery shall be during normal business hours; or

(b) by telegraph ... Notices so served shall be deemed received ... eight hours after the time of transmission or at the commencement of the next ensuing normal business day. whichever is the later; or

(c) by mailing them first class ... registered post, ... notices so served shall be deemed to be received .... on the second day, (excluding as the second day, Saturdays, Sundays and Statutory Holidays) following the mailing thereof ... (emphasis added).

From a practical operating aspect, the notices clause is probably one of the most important in an agreement. Whether one has given or received notice, it is vital to know how much time is allowed, especially if an election is required by the notice. This fact explains the specifics included in the clause. But the precision that an operator may require has not necessarily been achieved in this clause and one may wish to re-examine one's boiler plate provision.

One can speculate as to when the notice requiring action was given and therefore when the time for reply expired. For example, clause 1002 of CAPL dealing with proposals for independent operations provides in part:

Each receiving party shall give notice to the proposing party within thirty days after receipt of the operation notice ...

Subclause $1008(\mathrm{c})$ provides that:

Where a drilling rig is in location, the period for response to the operation notice under clause 1002 ... shall be reduced to 48 hours...

While in some circumstances (such as a rig on location) the proposing party would probably deliver notice personally or by telegraph, it may give notice by registered mail. Subclause 2201 deems that notice "to be received by the addressee on the second day ... following the mailing thereof". Assume that the second day was neither a Saturday, Sunday or statutory holiday. The notice in that case is "deemed" received "on the second day". When, therefore, does the 48 hours commence to run? It could be argued that there are five points in time when the notice period commences:

1. the beginning of the second day - eg. 12:01 a.m.;

2. the beginning of business hours in the addressee's office - eg. 8:00 a.m.;

3. the actual hour on the second business day at which the notice was received - assuming that it was received on the second day at all;

4. at the close of business in the addressee's office on the second business day; or

5. at midnight at the end of the second business day.

One may also be confronted with the rule of construction, occasionally applied, that the date of receipt is excluded in the calculation of time, so that the time does not begin to run until the day after the date of receipt or deemed receipt of notice - regardless of whether given by mail, telecommunication or personally. If that rule is applicable, at what time of the day following is the notice period deemed to com- 
mence? The problem may be excessively dramatic when the time for response is brief and measured in hours, but it is just as real if deadlines are approaching on a longer election period.25

Let us assume that because of the time constraints the "receiving party" has elected to convey its election by personal service by "leaving" it "with the party . . . to be served at that party's address ..." The CAPL form does not simply provide that the notice may be left, properly addressed, at the office of the addressee, but must be left "with the party ... to be served". If that party is an individual and is at that address, no problem will arise; but if a party is a corporation, does the word "served" require that the notice be "served" as prescribed by Alberta Rule of Court 15(2)(b)? The context indicates that there is a difference between the word "served" and the word "delivered". Assume that the president of the corporation has been cornered in his office during normal business hours and his corporation is therefore "deemed" to have received the notice "when actually delivered". Does that mean the day, or does it mean the hour? If the response is that "when delivered" necessarily means the actual moment, why is it necessary to "deem" anything about the time at all? To quote only one statement that imports a conclusive presumption in the expression "deem": 26

Generally speaking, when you talk of a thing being deemed to be something you do not mean that it is that which it is deemed to be. It is rather an admission that is is not what it is deemed to be, and that, notwithstanding it is not that particular thing, nevertheless . ... it is deemed to be that thing.

Further, whatever one may think is the appropriate time for commencement of the notice period, the served president may think differently.

While not suggesting that there are no answers to these queries, the speculation involved in arriving at the answers should be avoided

25. The various conclusions at trial and on appeal in Goldstein et al. v. Grant [1978] 18 0.R. (2d) 241 illustrate that the possibilities and problems described are not frivolous speculation. The trial judge held that the notice "deemed" to have been received on a certain day was received at 12:01 a.m. on that day. In the Court of Appeal, one of the judges held that because of wording, the notice clause did not apply to the notice given which was therefore effective when actually delivered. But if it did apply, it was to be deemed received at the last second, and not the first, of the deemed date. Another appellate judge excluded Saturday as the deemed date of receipt even though the agreement did not exclude Saturday (non of the other judges excluded it). He held, therefore, that the notice period commenced to run at midnight Sunday, presumably on the basis that he deemed the notice to have been received on Monday; the third judge on appeal appeared to agree with the trial judge.

One must also keep in mind the old rule laid down in Henthorn v. Frazer [1892] $2 \mathrm{Ch}$. 27, adopted recently in Pearce v. Transportation Fire and Casualty Co. et al. [1978] 18 0.R. (2d) 569 at 574:

Where the circumstances are such that it must have been within the contem. plation of the parties that, according to the ordinary usages of mankind, the post might be used as a means of communicating the acceptance of an offer, the acceptance is complete as soon as it is posted.

That rule may be construed as being limited to offers and acceptances. In addition, the Post Office Act, R.S.C. 1970, C. P-14, s. 41 stipulates:

41. Subject to the provisions of this Act, and the regulations respecting undeliverable mail, mailable matter becomes the property of the person to whom it is addressed when it is deposited in a post office.

Of course this provision deals with property and not with communications per se.

26. R. v. Norfolk County Council (1891) 60 L.J.Q.B. 379, per Cave J. at 380. 
under circumstances where the served party should be more concerned with the problems of clearing the swamp than the accumulation of alligators around his legs. If the pressure is great, the receiving party may be obliged to assume the worst possible situation for calculating the time limitations, and may have to make an unnecessarily hasty decision. ${ }^{27}$

The foregoing exhausts neither the subject not the ramifications of the CAPL provision. It is simply suggested that a re-examination of standard notices clauses may be beneficial. It may be that the notice by mail provision ought to be removed.

\title{
IV. ADVANCES - OPERATOR'S REMEDIES AND LIEN
} Clause 503 of CAPL provides in part that:

\begin{abstract}
The Operator may . . . require each Joint-Operator to advance its proportionate share of all costs and expenses to be incurred for the joint account. If the Operator so elects . . . each Joint-Operator shall pay the Operator its proportionate share of the costs and expenses so estimated or secure the payment thereof in a manner satisfactory to the Operator ...
\end{abstract}

Clause 505 provides in part:

(a) The Operator shall have a lien on the interest of each Joint-Operator in the joint lands and in the production, wells and equipment . . . to secure payment ...

(b) If a Joint-Operator fails to pay or advance any of the costs . . . and the default continues for 30 days ... the Operator may ...

(iii) enforce the lien created by the default in payment by taking possession of ... the interest of the defaulting Joint-Operator in the joint lands or in all or any part of the production therefrom and equipment thereon; and the Operator may sell and dispose of any interest, production or equipment of which it has so taken possession ...

The consideration of these extracts will be limited to determining whether the Operator ought to feel confident that the provision has provided him with any real security.

If a Joint-Operator fails to pay or secure to the Operator the advance that the Operator has requested, that failure probably merely confirms the Operator's suspicion that the Joint-Operator is in financial trouble. He can then withhold information from the JointOperator. If there is production, he can treat the default as an assignment of the proceeds of the sale of any such production. The Operator can also attempt to take the lien remedies quoted above. It should be kept in mind that there is nothing to relieve the Operator from its obligations to operate. If, for example, the Operator is drilling a well, he would be obliged to continue that drilling and to perform his obligations both to the defaulting Joint-Operator as well as to any other Joint-Operators by virtue of the umbrella obligation in the agreement to "carry on all operations diligently, in a good and workman-like manner, in accordance with good oilfield practices ...". If there is no production for the joint account from other sources, what does that purported lien with the right of sale really give the Operator who is drilling a well? Apparently, he is given the right to sell equipment which he is using to drill the well and which he owns in proportion to his participating interest in the joint venture. Surely even the most

27. For a discussion of problems inherent in the meaning of "deem", even without any concerns relating to time of delivery, see Raney, Case Comment, (1960) 38 Can. Bar Rev. 413. 
vengeful Operator would perceive that the prosecution of the venture was of greater significance than the settlement of the debt, all the while muttering, "Some remedy!"

In the meantime, the Operator has drilled the well. If it comes up dry, the Operator inevitably pays the whole bill himself; if it encounters production, the defaulting non-Operator becomes entitled to enjoy his full share of production lafter the Operator has reimbursed himself for an amount equal to that non-Operator's owed contributions). In other words, the Operator has drilled an independent well in which the defaulting non-Operator has the right to participate without the payment of any penalty even remotely comparable to that required in an independent well situation.

\section{OPERATOR'S LIABILITY}

Clause 401 of CAPL provides in part:

The Operator shall not be liable to the Joint-Operators for any loss or damage except for any loss or damage resulting from gross negligence or wilful midconduct ...

Under Clause 402:

Each of the Joint-Operators, proportionate to its participating interest . . . indemnifies ... the Operator against ... liability to any third person .... provided, however, that the Operator shall not be indemnified ... for any loss, damage claim or liability, resulting from the gross negligence or wilful misconduct of the Operator...

However, clause 304 of CAPL says:

The Operator shall carry on all operations diligently, in a good and workman-like manner, in accordance with good oilfield practices, and in accordance with the regulations.

This group needs no recitation of authorities to establish that there is a considerable disparity between the duties of care by which "gross negligence and wilful misconduct" and "good and workman-like manner" are adjudged. The necessary question, therefore, is how do these provisions, which are standard in petroleum industry operating agreements, fit together? If they do not, which of these provisions governs the standard of the Operator's performance?

There is no authoritative answer to these questions. But even if the Joint-Operators suffered loss or damage by reason of the Operator's failure to conduct operations "diligently, in a good and workman-like manner", it is submitted that the Joint-0perators would have no remedy against the Operator unless the failure or departure in question fell within the realm of "gross negligence or wilful misconduct". A non-Operator's technical people may wish to make a great issue about "good and workman-like" performance if they consider the Operator's activities wanting, and they may be successful on a practical level. However, counsel should have a case of serious misconduct on hand before recommending litigation or arbitration on the matter.

Probably no totally satisfactory accommodation of these inconsistent provisions is available. Presumably, the philosophy that permits their inclusion is that the non-0perator also must accept some degree of risk in a joint venture; he tries to minimize that risk by being selective in the choice of the Operator. However, once having done so, he has essentially waived indemnification for his share of losses other than that attributable to gross negligence or wilful mis- 
conduct. Of course, the aggrieved non-Operator does have a remedy, if one is prepared to accept that characterisation: he can turn to the conventional "Replacement of Operator" provision. Indeed, under the CAPL terms, the dissatisfied non-Operator may have a remedy for breach of the "good and workman-like obligation". Under subclause 202(d):

The Operator shall be replaced ...

(d) If the Operator defaults in its duties or obligations or any of them hereunder and does not commence to rectify the default within 30 days after written notice from a majority of the Joint-Opertors .... specifying the default and requiring the Operator to remedy the same.

The difficulties and burdens confronting a party attempting to resort to this remedy for alleged default in cases of marginal performance by the Operator are self-evident.

One last observation can be made about the standard of performance imposed on the Operator under the CAPL form. Many conventional agreements include among the non-Operator's rights of action against the Operator the right to recover damages for failure to make rental or other periodic payments required to maintain the leases, subject to the joint venture, in good standing. The Operator is absolutely responsible in those cases. Under clause 309 of the CAPL form, "Maintenance of Leases", the maintenance obligation is separated from the express statement for liability for gross negligence and wilful misconduct in clause 401. Accordingly, if the foregoing assessment regarding the non-Operator's limited right of remedy against the Operator is correct, it is suggested that the Operator would not be liable to the non-Operator under the CAPL form for losses or damages that a non-Operator would incur or suffer as a result of the Operator's failure to pay rentals and other periodic payments required to maintain the lease in force, unless such failure was established as being the result of gross negligence or wilful misconduct. It is not clear why the aggrieved non-0perator should be proscribed from recovering in this notoriously sensitive area.

\section{CONCLUSION}

These are merely some anecdotes from the many available about boiler plate clauses. Perhaps they have served to unsettle, at least slightly, the insouciance with which these and other standard provisions are conventionally adopted. 